Article

\title{
Geotourism at the Natural Park of La Garrotxa Volcanic Zone (Catalonia, Spain): Impact, Viability, and Sustainability
}

\author{
Llorenç Planagumà 1,2 (iD) and Joan Martí ${ }^{3, * \text { (iD) }}$ \\ 1 Tosca, Environment Services, 17800 Olot, Spain; llplanaguma@gmail.com \\ 2 Departament de Geografia, Institut de Medi Ambient, Facultat de Lletres, Universitat de Girona, \\ 17071 Girona, Spain \\ 3 Institute of Earth Sciences Jaume Almera, CSIC, 08028 Barcelona, Spain \\ * Correspondence: joan.marti@ictja.csic.es; Tel.: +34-934-095-410
}

Received: 22 June 2018; Accepted: 2 August 2018; Published: 7 August 2018

\begin{abstract}
La Garrotxa Volcanic Zone is a suitable case study to analyze the impact and sustainability of geotourism on a protected volcanic field, as it has allowed the transformation of a poorly known territory into one of the best known and most visited geosites of Catalonia (Spain). The protection of this volcanic area represented the end of legal and illegal quarrying activities that significantly damaged most of its volcanoes, but also provided an opportunity to develop the zone for tourism. We compiled the available information from its establishment in 1982 as a natural park by the Catalan Government to the present day, in order to analyze the socio-economic impact of geotourism on this protected area and its surroundings. We paid attention to its evolution in terms of the number of visitors, the social and economic consequences that this type of tourism has had, and whether it is compatible with the conservation of natural assets, especially geological ones. We also studied the role that the co-management of the protected space by local administrations and private entities has had on its sustainability. The results obtained are relevant to visualizing the viability of geotourism in a protected area by combining the economic drive and the conservation of natural assets. Spaces such as La Garrotxa Volcanic Zone represent natural laboratories where we can observe the success of the application of environmentally friendly policies with a positive socioeconomic impact on geotourism.
\end{abstract}

Keywords: Catalan volcanic zone; geological heritage; geotourism; monogenetic volcanism; Spain

\section{Introduction}

Geotourism is an increasing business in modern society. Geotourism is a knowledge-based type of tourism that looks for an interdisciplinary integration of the tourism industry with the conservation and interpretation of geological heritage at the same time as it promotes the economic and social development of local communities [1-3]. In this sense, it is considered a sustainable type of tourism that lies at the intersection between tourism as a global phenomenon and sustainable development as a global task [4-7].

One particular type of geotourism is "Volcano Tourism" [8-11], as volcanoes and volcanic terrains have a worldwide fascination and many are visited by huge numbers of people each year (e.g., Iceland, Canary Islands, Hawaii, Yellowstone, Etna, and Vesuvius). These visits to both live and extinct volcanic landscapes provide much public recreation, adventure, and enjoyment. They also afford opportunities to observe, learn, and appreciate the power and role of volcanism in building the planet's surface.

The benefits of geotourism can be measured through environmental, social, and economic indicators, such as increased natural heritage conservation, improved social benefits like self-esteem, 
jobs, and incomes [1-3]. Since geotourism adds values to local or regional communities, it economically supports geological heritage conservation [2]. Consequently, there is a need to gain a greater understanding of the nature and characteristics of geotourism, especially in relation to the importance of placing geology at the center of a destination, but also in regard to its characteristics, impacts, and management.

Most protected volcanic areas have generated exciting tourism products and opportunities for public use, which provide substantial community benefits. Several studies have proposed guidelines for planning and managing sustainable tourism in protected areas $[12,13]$ and a few of them include the analysis of revenue sharing in such areas $[14,15]$. However, we still need to estimate the benefits of tourism in many protected volcanic areas and how to maintain and increase this business in a manageable and sustainable way. Unfortunately, due to the relatively early stages of volcano tourism, there are still very few data compilations concerning the exploitation and benefits from volcano tourism (e.g., $[14,15])$. Therefore, many more case studies need to the analyzed in order to quantify and evaluate this tourism sector in-depth and propose innovative products that could guaranty the sustainability of volcano tourism.

The natural park of La Garrotxa Volcanic Zone is an area of great geological, botanical, faunistic, and landscape value and, although it is an area with considerable human activity, its landscape and unique natural environment have been well-preserved [16] (Figure 1). This protected area includes the northern side of the La Garrotxa monogenetic volcanic field, which contains about 50 well-preserved volcanic cones that exhibit a large diversity of strombolian and phreatomagmatic volcanic products (Figure 1) $[17,18]$. The volcanic activity and humid climate characteristic of this area gave rise to the fertile soils [19] that provide the area with excellent biodiversity.

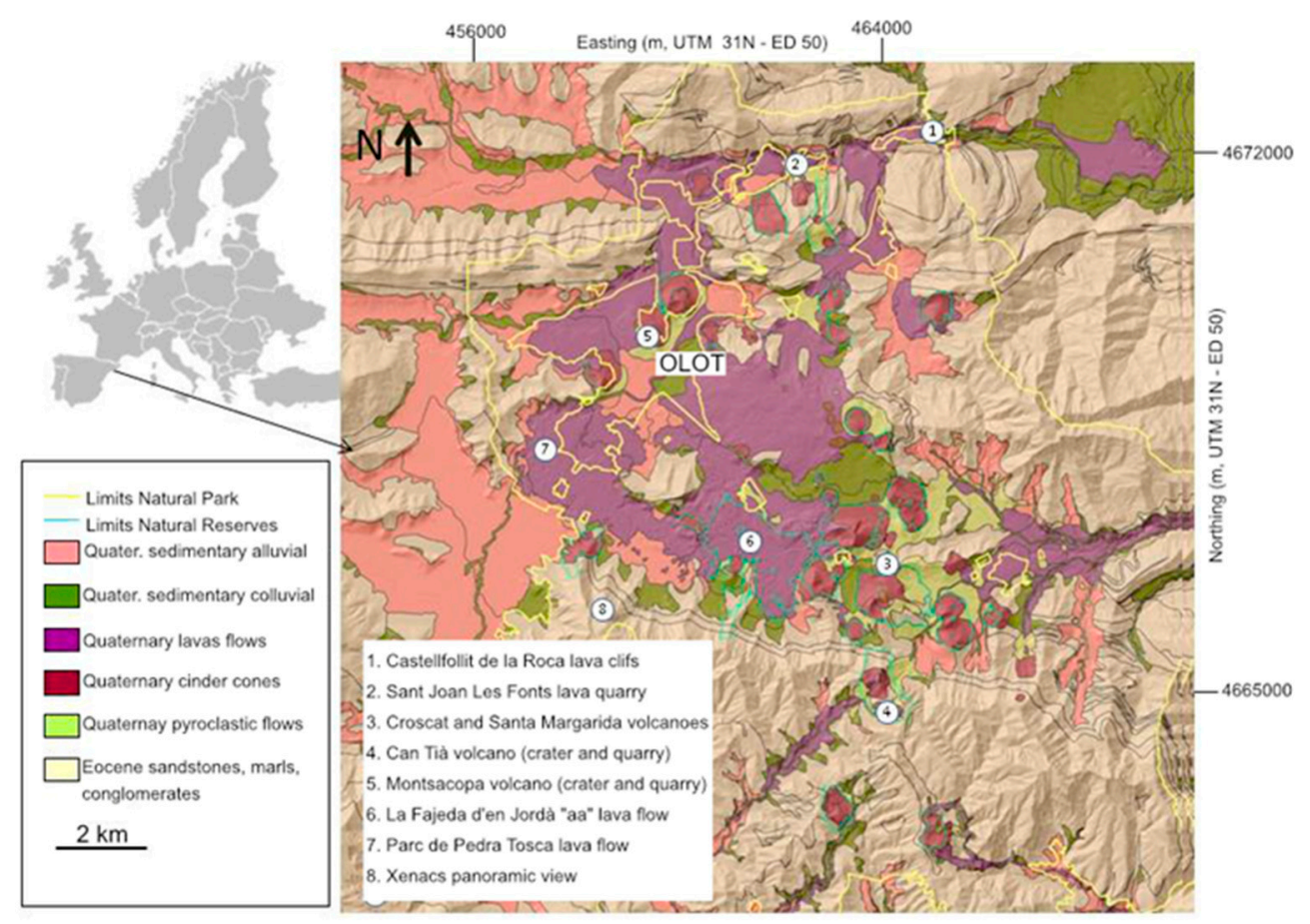

Figure 1. Simplified geological scheme of La Garrotxa Volcanic Zone with indication of the borders of the natural park and the nature reserves and places of geological, natural, and cultural interest.

Since its declaration as a natural park in 1982, but particularly since 1986, when an administration team took responsibility for its management, this area has become an important lure for local, national, and foreign tourism, transforming this poorly known territory into one of the best known and most visited geosites of Catalonia. As an example of volcano tourism that has been exploited in a sustainable 
way, in this study, we describe how La Garrotxa Volcanic Zone was protected in a natural park and how the different actions taken under this protection contributed to a sustainable geotourism that has led to important socio-economic benefits for the region. This is a particular case study that, together with the others that already exist, will contribute to a better understanding of the possible benefits and threats of volcano tourism.

\section{Geographic and Geological Setting}

Geologically, La Garrotxa Volcanic Zone is one of the best-preserved volcanic regions in the Iberian Peninsula from those pertaining to the Neogene-Quaternary basaltic volcanism of the European rifts system $[17,18,20]$ (Figure 1), with intense human activity, which at times, impedes the conservation of the land. Volcanic activity began some 700,000 years ago in La Garrotxa [20], and continued until the early Holocene with the eruption of the Croscat volcano about 10,000 years ago [21]. In total, at least 50 eruptions have been identified [2,3], leading to volcanic cinder and spatter cones, maars and tuff rings, as well as several lava flows that filled the valleys in the area. The stratigraphic, structural, and hydrogeological characteristics of the substrate above which these volcanoes were emplaced favored phreatomagmatic activity, which combined with the magmatic Strombolian activity, caused a large variety of eruption sequences $[17,18]$.

The richness of volcanic soils and the climate is one of the other determining factors in the zone, where the Mediterranean climate, characterized by mild winters and hot summers with low rainfall, mixes with the Atlantic climate, where rain and temperature inversion is abundant in summer; whereas in winter, this inversion causes lower temperatures and frequent frost. The diverse relief, the confluence of the Mediterranean and Atlantic climates, and the diversity of substrates lead to a great variety of plant species and also to a wide variety of natural environments, which has allowed a very diverse and interesting faunistic population to exist, characterized by the cohabitation of typical Mediterranean fauna with typically Central European species [22].

The landscape, shaped by volcanic activity, geomorphological agents, and humans, is one of the most distinctive features of this area. For many centuries, human presence was associated with the exploitation of agricultural, livestock, and forest resources, and the landscape became a harmonious mosaic of fields, pasture, and woodland that supported the family economy. The craft and industrial activity contributed towards great social and landscape change.

\section{History of the Protection of the Zone}

The urban and industrial growth of the 1960s led to a number of serious environmental problems: extraction of volcanic tephra, urban growth that did not respect the environment, river pollution, and the proliferation of uncontrolled dumping. The combination of all these problems posed a serious threat to the natural assets. The need to protect this natural space triggered a series of sociocultural movements that culminated when the parliament of Catalonia, in 1982, passed the law to protect La Garrotxa Volcanic Zone, converting it into a natural park. The goal was to protect its geological, botanical, and landscape assets, and to combine the conservation of the zone with its economic development. Currently, this protected space covers 15,308 ha, where more than 40,000 inhabitants are distributed across 11 towns, and includes 28 nature reserves.

The mining exploitation of the Croscat volcano (Figure 2) served as a springboard for demands for the conservation of the natural heritage and the volcanoes in the area. Its history ties in very much with the geotourism that began to be promoted in the area after the declaration of the natural park of La Garrotxa Volcanic Zone. Table 1 summarizes the activities and actions taken before and after the declaration of the natural park. 


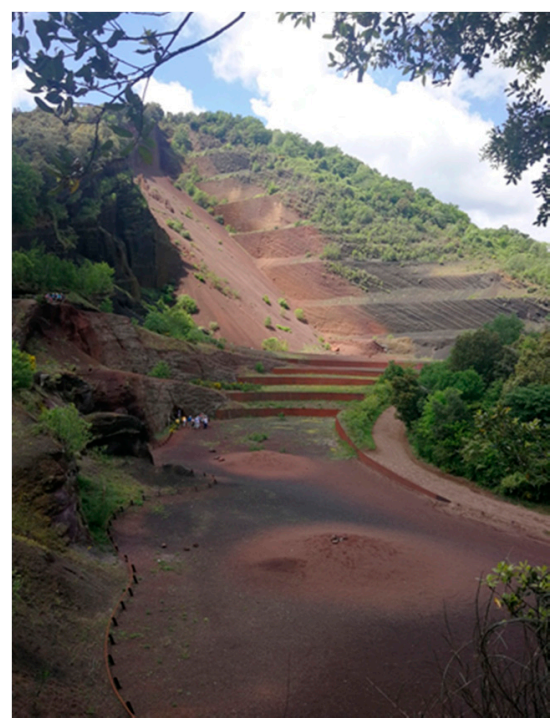

Figure 2. Tephra quarry at the Croscat volcano restored in 1995. This is one of the outcrops of interest for the Natural Park, and has a special protection regulation.

Table 1. Chronology for the preservation of the La Garrotxa volcanoes, which illustrates how they passed from an extractive activity to a natural reserve and a touristic attraction.

\begin{tabular}{|c|c|}
\hline Year & Description \\
\hline 1966 & $\begin{array}{l}\text { The executive management of mines authorizes the mining concession "Santa Margarida" (no. 3140), with a } \\
\text { surface area of } 861 \text { ha, as a result of a report from the laboratories of the Higher Mining Council, which } \\
\text { considered that pumice stone would be obtained from the extractions. The concession covered the zone of the } \\
\text { Croscat, Santa Margarida, Puig de Marinyà, and Puig Astrol volcanoes. }\end{array}$ \\
\hline 1976 & $\begin{array}{l}\text { Awareness-raising campaigns were held for scientists to study the volcanic region and they were asked to } \\
\text { support the application for the zone to be declared a natural park. A vast response was received. } \\
\text { Safeguarding campaign promoted by scientists from the zone with the backing of sociocultural institutions } \\
\text { and political groups from the region in the 1970s. }\end{array}$ \\
\hline 1977 & $\begin{array}{l}\text { Via a resolution, the Directorate General of mines and construction industries of the Ministry of Industry } \\
\text { consolidated the mining rights of the "Santa Margarida" concession in favor of Minas de Olot, SA, for a } \\
\text { period of } 90 \text { years. }\end{array}$ \\
\hline 1982 & $\begin{array}{l}\text { Law 2/1982, of } 3 \text { March, for the protection of La Garrotxa volcanic zone with the creation of the natural } \\
\text { interest area of La Garrotxa Volcanic Zone. }\end{array}$ \\
\hline 1985 & Passing of Law 2/85 of natural spaces in which it becomes a natural park. \\
\hline 1990 & $\begin{array}{l}\text { Halting of the clay extractions as a result of the autonomous government of Catalonia purchasing the } \\
\text { majority of the shares in the company. }\end{array}$ \\
\hline 1992 & $\begin{array}{l}\text { It took nine years after the law was passed to finally execute that stipulated in the law. From then on, } \\
\text { intervention in the natural park consisted of restoring the zone occupied by the uncontrolled dumping of } \\
\text { town waste. It was the first case in Catalonia that a farm with conservationist goals was expropriated. In total, } \\
77.2 \text { expropriated hectares were turned into the only fully public nature reserve to exist in La Garrotxa } \\
\text { volcanic zone natural park. }\end{array}$ \\
\hline 1994 & $\begin{array}{l}\text { Restoration works begin on the clay pits of the Croscat volcano and the former dump, with a view to } \\
\text { recovering the morphology of the base of the volcano, thereby preventing its erosion; as well as the pastures } \\
\text { and flat zones; and reintroducing autochthonous species from the zone into the steepest areas, to integrate } \\
\text { them into the landscape and facilitate public access for educational purposes since the extraction of more } \\
\text { than } 2,200,000 \mathrm{~m}^{3} \text { of clay left two large vertical cuts that were difficult to restore. }\end{array}$ \\
\hline 1995 & $\begin{array}{l}\text { The restoration works on the clay pit and the sealing up of the dump begin. The main criterion of this activity } \\
\text { was to organize the space, creating a network of paths, to render it apt for essentially pedagogic use. Today, } \\
\text { the Croscat clay pits are one of the most visited parts of the natural park. }\end{array}$ \\
\hline
\end{tabular}




\section{Tourism Resources in the Area}

La Garrotxa Volcanic Zone is the only zone for volcanic geotourism with well-preserved volcanoes located in the center of the Pyrenees-Mediterranean Euroregion, which encompasses the French region of Occitanie, and the autonomous regions of Catalonia and Aragon in Spain. This Euroregion has a population of 14,529,912 over a distance of less than $300 \mathrm{~km}$. This is the potential audience visiting these volcanoes, since it is a unique destination. The area has different places of geographical interest, with natural and cultural resources, which complement each other perfectly and determine the attractiveness of the zone.

According to the statistics provided by the natural park, in 2010, La Garrotxa region received 355,735 visitors, which is 53,000 more than in 2001 [23] (Figure 3). Of these visitors, 48\% were families and $37 \%$ were couples, $81 \%$ were Catalans (i.e., local tourism), and $76 \%$ of the visitors came to see the volcanoes [23].

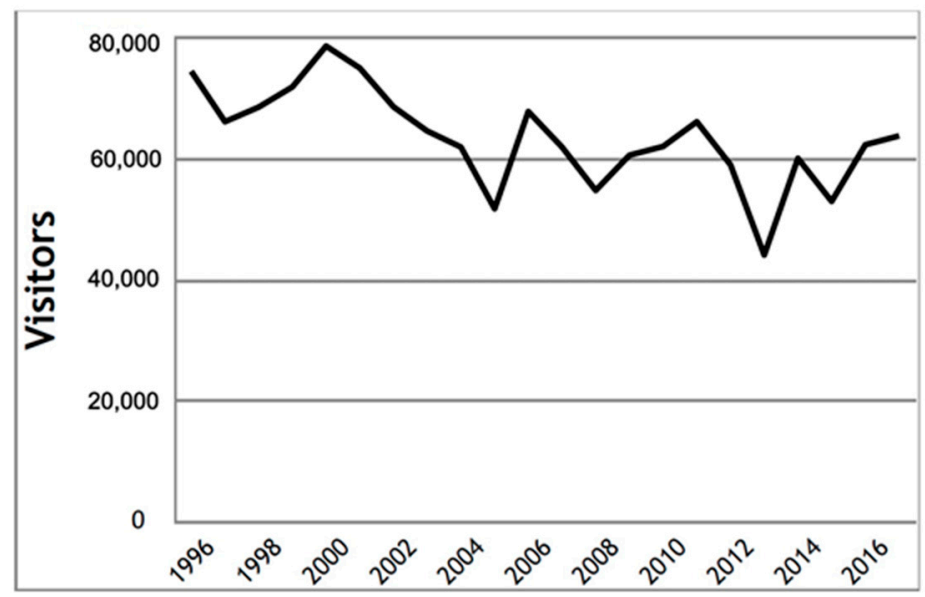

Figure 3. Graph of visitors who attended the information centers of La Garrotxa Volcanic Zone Natural Park. The decline in the number of visitors in 2005 is due to the closure of the Casal dels Volcans for restoration works, and in 2013 to the closure of the centers due to economic restrictions $[23,24]$.

\subsection{Outcrops and Places of Geological Interest}

La Garrotxa Volcanic Zone displays several places of geological interest, from which eight are remarkable [25] (Figures 1 and 4). (1) To the north of the zone stands the lava flow cliff of Castellfollit de la Roca, where the town is perched on top of a 50-m crag of basalt columns. (2) Nearby are the former quarries of Sant Joan les Fonts, where different lava flows with different internal morphologies (e.g., columnar joints, tumuli, etc.) can be observed. (3) The most recent volcanic activity is located in the center of the volcanic zone, with easy access to the cinder cone of the Croscat volcano, to the Santa Margarida maar-type crater and its deposits, to the tephra quarry of the Croscat volcano, and to the Rocanegra volcano. (4) Another place of geological interest is the Can Tià volcano, its maar-type crater, and the outcrop that corresponds to an old quarry, which shows the full stratigraphic succession of this volcano. (5) The Montsacopa volcano in Olot, a route that reveals a cinder cone with a circular crater at the top and an interesting route through its tephra pits that serve to interpret the formation of the volcano. (6) The Jordà beech forest is a geological, natural, and cultural asset that leads visitors through the well-preserved "aa" type lava flow from the Croscat eruption; this type of beech forest is unusual at this latitude, as it is more common in Atlantic climates than Mediterranean ones [19], and has served as a source of inspiration to poets and painters alike. (7) The Pedra Tosca Park in the Tosca Forest is another place located at the top of a lava flow; in this case, from the Puig Jordà volcano. This is a place of geological interest due to the large number of rootless spatter cones that can be observed on this lava, but also of cultural interest for the dry-stone constructions, shelters, and land 
clearing present. (8) The last main place of geological interest is the Xenacs viewpoint where the zone's landscape and relief can be contemplated and understood, as well as the location of the volcanoes.
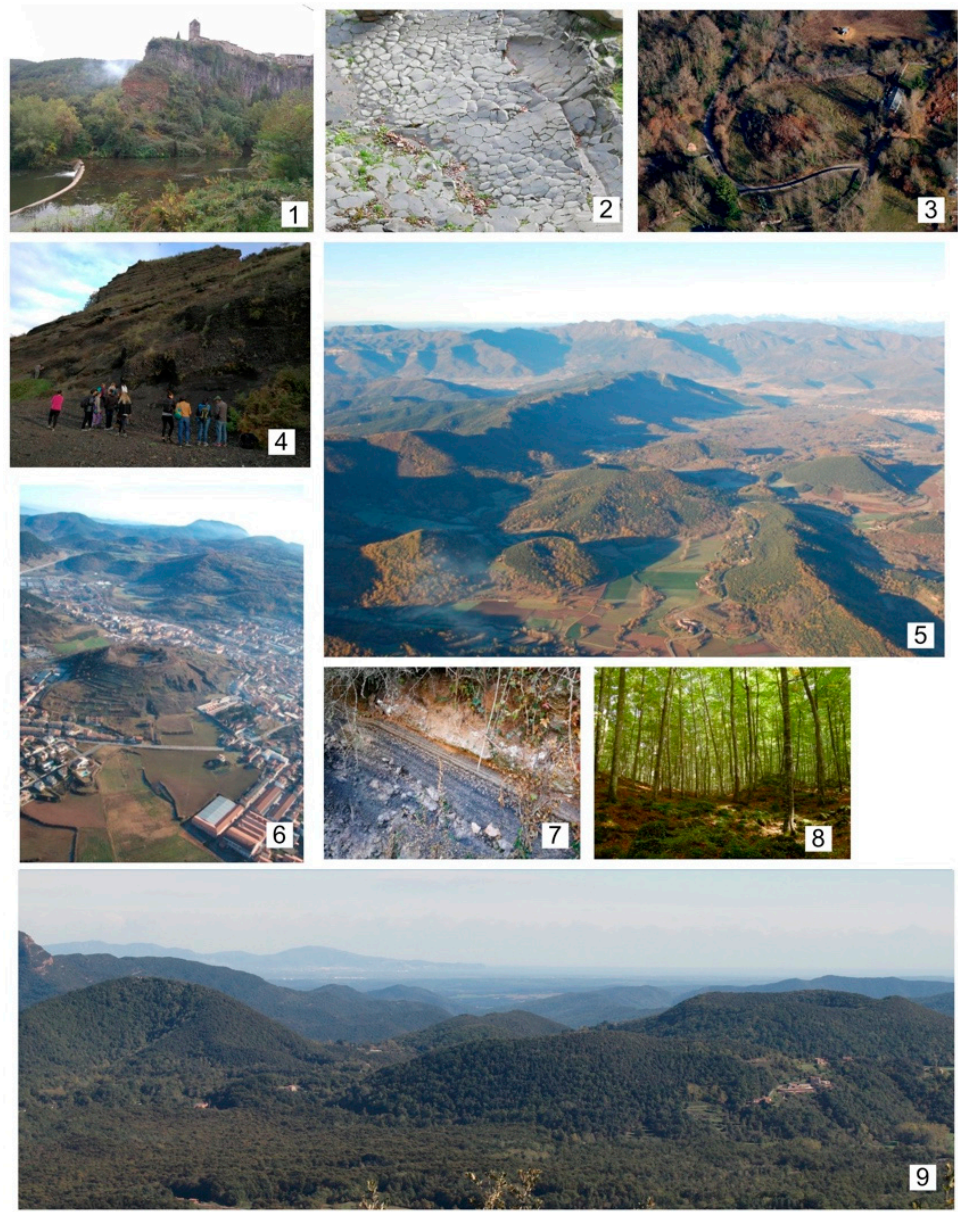

Figure 4. Photographs of the main geosites. (1) Castellfollit de la Roca lava cliff; (2) Detail of Sant Joan Les Fonts (Moli Fondo quarry) lava flows; (3) Aerial view of a rootless scoria cone at the Pedra Tosca Park; (4) Montsacopa volcano quarry; (5) Aerial view of the Croscat and Santa Margarida volcanoes; (6) Aerial view of the Montsacopa volcanoes; (7) Pyroclastic deposits at the Can Tià volcano quarry; (8) La Fageda d'en Jordà lava flow; (9) Landscape view of Crosca (left) and Santa Margarida (center) volcanoes from Xenacs.

\subsection{Other Places of Natural and Cultural Interest}

In addition, this volcanic area has several places of cultural, natural, and intangible interest [26] (Figure 5), from which the following seven are the most remarkable. (1) In Olot, we find the Parc Nou-Moixina, a place that holds the last pockets of English oak in the Olot valleys, a humid area, as well as the Volcano Museum. (2) Olot's old quarter and its modernist architecture built during the industrial growth of the 18th century are also notable. (3) The Colltort Castle between Santa Pau and Olot is a place to observe volcanic cones, craters, and landscape, and is a prime example of the 15th-century Rebellion of the Remences, the first peasant revolution to occur in Europe. (4) Santa Pau is a town built around a castle during the 13th and 14th centuries, with an arcaded square where a market was held. (5) Besalú, the former capital of the region, is a town with excellently preserved ancient medieval buildings, an impressive bridge, squares, miqwe jueu (baths), and churches and monasteries. (6) The town of Sant Feliu de Pallerols is one of the finest examples of a medieval town with a holy space. (7) Finally, the intangible value of the gastronomy based on natural products, such as local beans, meat, and cured cold cuts, is falling under what is locally known as volcanic cuisine. 


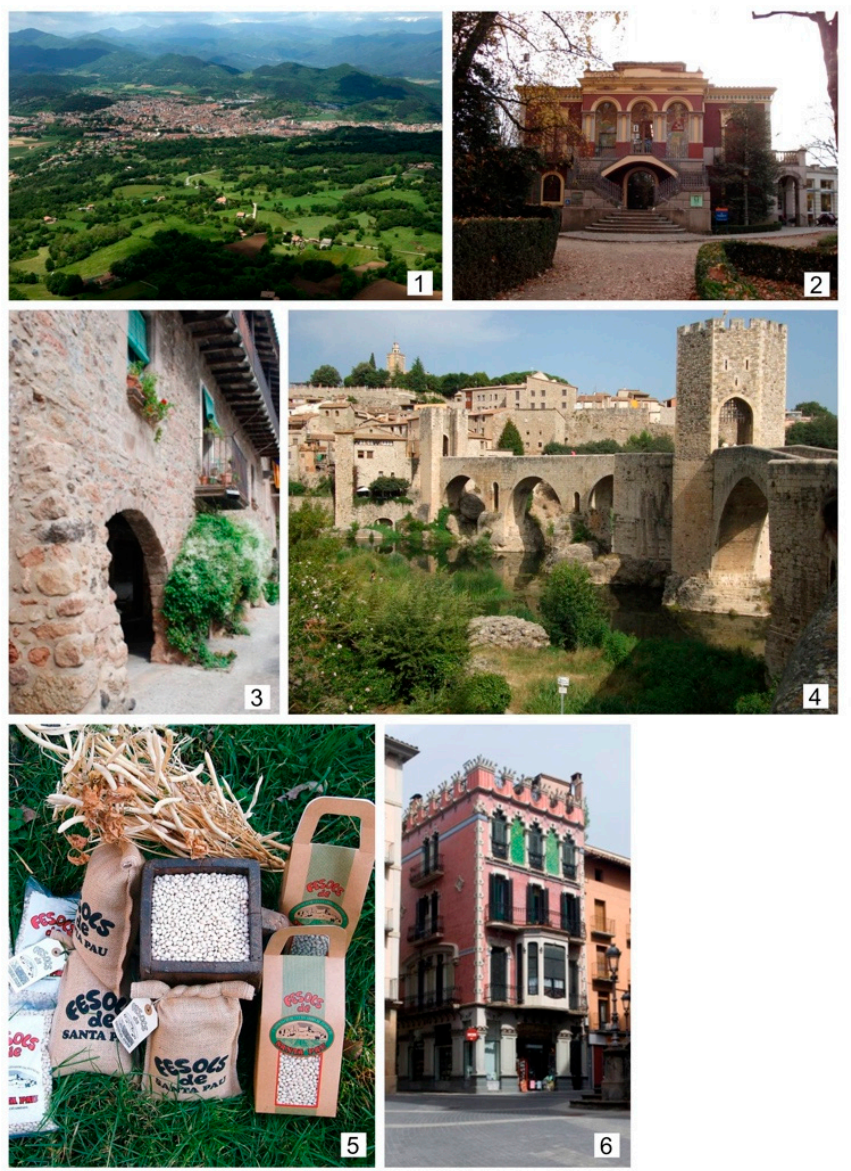

Figure 5. Photographs of the main natural and cultural sites. (1) Olot city; (2) Volcano Museum (Casal dels Volcans); (3) The medieval centre of Santa Pau; (4) Besalú medieval town; (5) Santa Pau haricot beans; (6) The Gaietà Vila Art Nouveau house in Olot. Source: Documentation Centre, Garrotxa Volcanic Zone Natural Park.

\subsection{Tourism Interpretation Centres}

During the creation of the natural park, a series of centers were established to disseminate the information of the main values of the park among the visitors. The management and number of these tourism centers has fluctuated over the past 30 years according to the conservation policies of the natural environment (Table 1). The natural park has created four centers for visitors: The Casal dels Volcans, at the Parc Nou-Moixina in Olot; Can Serra, at the entrance of the nature reserve of the Jordà beech forest, on the road to Santa Pau; Can Passavent, at the entrance of the nature reserve of the Croscat volcano; and the Sant Feliu de Pallerols station, which only operated as a center for the park for three years. The goal of these centers is to inform and educate visitors about both the zone and respecting the natural heritage. In recent years, the centers have been attended by more than 1,500,000 visitors, with an average of 65,000 visitors per year from the more than 300,000 who visit the park, which means that $1 / 5$ of the total visitors of the park per year are informed, according to the statistics provided by the natural park.

\subsection{Itineraries to Visit the Volcanoes}

The volcanic zone has 25 itineraries of varying durations, from as short as $30 \mathrm{~min}$ (the Joan Maragall itinerary to the Jordà beech forest) to longer ones such as itinerary 19 to visit the Can Tià and Fontpobre volcanoes, which takes five hours (Figure 6). Some of these itineraries, such as the Joan Maragall route, have overcrowding issues in the autumn and Easter, with an average of 2025 
visitors per day, according to the statistics provided by the natural park in 2015. For another itinerary, the one that takes visitors to the Croscat volcano tephra quarry (itinerary 15), the number of visitors that attended in the same year in the Can Passavent information center was 37,614, of whom almost half, 15,971, were school groups, as indicated by the Natural Park.

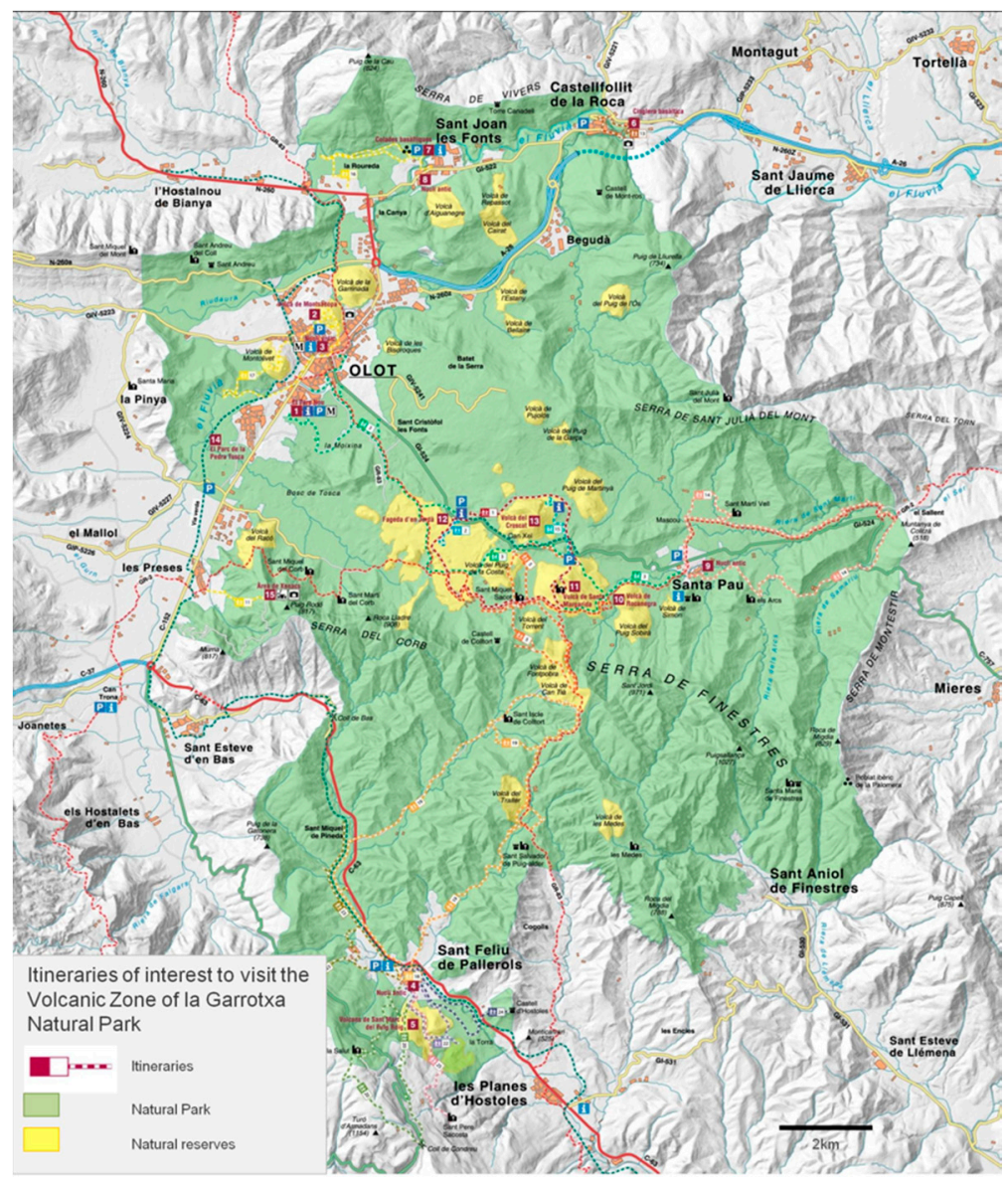

Figure 6. Itineraries scheme of the natural park of La Garrotza Volcanic Zone.

\subsection{Outreach}

In order to help visitors to understand the existing volcanic activity, several outreach products have been published with the goal of highlighting the interest of the zone for visitors, and to encourage visits that visit for more than one day. Among these outreach products, the "Field Guide of the La Garrotxa Volcanic Zone" [27] (Figure 7) documents how to observe and interpret the volcanic activity of this zone from twelve places of geological interest. Moreover, the volcanological map of La Garrotxa Volcanic Zone Natural Park [28] complements this guide and helps visitors to discover the volcanoes on every itinerary or in every place. In the information centers, visitors are provided with maps to visit the different places that are considered the most representative of the natural park. 


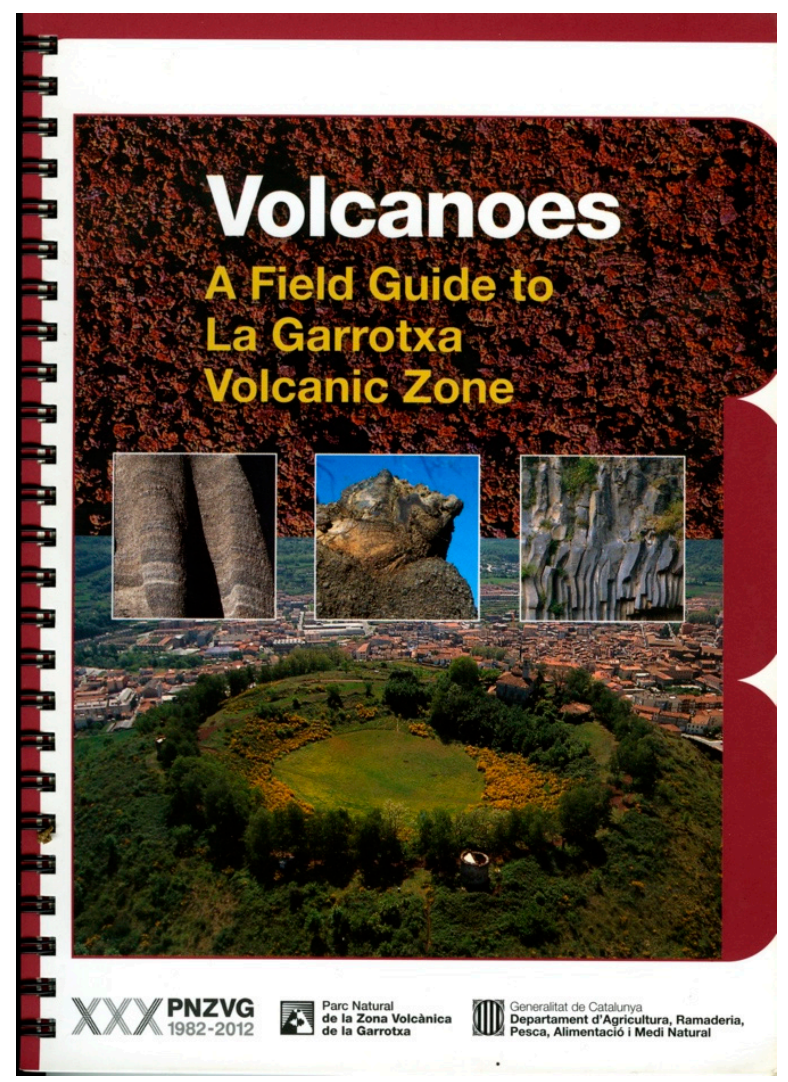

Figure 7. Front cover of the area's volcanic guide that was designed for users to interpret the zone's volcanic activity from a single publication. Hence, it has three parts: General description of volcanism, volcanic activity in NE Catalonia, and description of the outcrops of interest to interpret volcanic activity in the area [27].

\subsection{Education and Training}

Education is one of the essential strategic lines employed to preserve protected natural spaces [29]. Educational programs developed in the natural park of La Garrotxa Volcanic Zone are aimed at raising awareness among the population and visitors about the environment and volcanic activity through the assimilation of contents necessary to obtain skills, abilities, and the desire to participate in the prevention and solution of environmental problems. For this reason, the level of knowledge on the volcanological values of those people who live near the volcanoes and of those who visit them is important. Therefore, programs are required for both the local population and for visitors. Local residents need to understand volcanic activity and how to transmit their values to visitors, and as such, it is important to train all related workers in activities directly or indirectly related to tourism. A particular effort is made in training guides who take visitors to La Garrotxa Volcanic Zone, both through school groups and adult visitors. Approximately 60,000 schoolchildren visit the zone each year, and in effect, they constitute one of the main channels for the dissemination of the natural geological values and to increase awareness about their conservation. Therefore, we can say that since 1994, more than 1,500,000 students have visited the volcanoes of La Garrotxa, thus becoming a very significant figure that represents the majority of the school-aged Catalan population [29].

\section{European Charter for Sustainable Tourism}

La Garrotxa volcanic zone attempts to achieve sustainable tourism through the European charter for sustainable tourism (ECST) [30]. Through its principles and phases, this charter structures a strategy 
of sustainable local development. La Garrotxa Volcanic Zone was one of the first natural parks to carry out a pilot test in 2000 aimed at:

- Fostering the knowledge and support of protected natural spaces, which represent a fundamental part of our natural and cultural heritage, and which therefore must be conserved for the enjoyment of current and future generations.

- Orienting the management and tourism development of the protected spaces around sustainability, that is to say, making the conservation of the land's assets compatible with the satisfaction of private sector aspirations, the expectations of visitors, and the needs of the local population.

Initially, the natural park and the local governments undertook work according to the 10 principles established by the ECST:

1. To involve all parties related to tourism in the protected space and the surrounding areas in the development and management of the protected area.

2. To prepare and implement a sustainable tourism strategy and action plan for the protected area.

3. To protect and enhance the area's natural and cultural heritage, for and through tourism, and to protect it from excessive tourism development.

4. To provide all visitors with a high-quality experience in all aspects of their visit.

5. To provide visitors with adequate information about the special qualities of the zone.

6. To promote specific tourism products which help visitors to discover and understand the area.

7. To increase knowledge of the protected area and of sustainability issues amongst all those involved in tourism.

8. To ensure that tourism improves, and does not reduce, the quality of life of the local population.

9. To increase the profits derived from tourism for the local economy.

10. To control and monitor the flow of visitors to reduce their potential negative impact.

Later, in a second phase, a total of 18 companies from the private sector joined the charter and participated in the co-management of the natural park. As the main positive impacts, these companies highlighted: (i) the improvement of the relations and communication with the team managing the protected space; (ii) the collaboration with other companies associated with the ECST; (iii) the improvement in clients' behavior in the use of resource saving and efficiency based on information provided by the companies during the adhesion process; and (iv) encouragement of the support and promotion of local products and services associated with the tourism agri-food sector, crafts, etc.

One of the star products of the ECST is the network of itineraries called Itinerannia, which provides different itineraries for visiting and enjoying the landscape and natural values, such as the deposits and morphologies of the volcanic activity in the zone. In 2014, according to Turisme Garrotxa [31], the network received 67,850 walkers and an economic impact of 3,263,000.00 €.

\section{Threats to the Conservation of the Natural and Social Assets Due to Tourism}

The main problems that the increase of geotourism in areas such La Garrotxa Volcanic Zone encompasses are mainly related to the possibility of developing tourism based on short, low-quality visits, concentrated in time and space, and with serious overcrowding problems, causing a collapse of services and significantly lowering the quality of the visits.

In view of this situation, protected areas call for the need to manage, channel, and shape the affluence of visitors whilst respecting their traditional missions (i.e., the conservation and development of the territory). In the particular case of La Garrotxa, there are essentially three impacts and threats that are incompatible with the promotion of tourism: overcrowding, sustainable mobility and disparity in management policies, and cuts in the protected natural spaces applied in 2010.

The overcrowding in the zone occurs in the autumn, coinciding with visits to the beech forest to admire the red tones of trees and the volcanoes, especially the Jordà beech forest. For example, 
some $700 \mathrm{~m}$ in length of Itinerary 2 can be walked by 2025 visitors in one single day [32]. These are concentrated between 11 a.m. and 1 p.m., causing mobility problems and concerns with neighbors, in addition to effects on the environment. The goal is to be able to regulate this intensity of visitors through car parks, the payment of entrance fees, and future actions to promote sustainable mobility in the area, avoiding access with personal vehicles.

Since La Garrotxa Volcanic Zone became a natural park, the commitment from the administration responsible for the conservation of the natural heritage has been inconsistent, and the policy and management of nature has gone through different stages and periods [33], which reveal diverse sensitivities in relation to the way it is considered (social relevance) and managed (resources, strategies and instruments). Each phase has been characterized by common elements in governance (dividing responsibilities, tensions between administrations and governments, public-private relations, etc.). In turn, these phases have been subdivided into periods that define and characterize the action of the successive governments. The Natural Park has not been left unaffected by these occurrences (Table 1) and has seen its management and good reputation for conserving the geological heritage endangered. The reduction in the budget by half suffered in recent years due to the global economic crisis, represents a serious problem for the area. This has clear implications, although these have been mitigated through a key factor, which is the administrations' and local entities' participation in the co-management of the natural park (Table 2 and Figure 8).

Table 2. How policies related to the natural heritage of the government of Catalonia have affected La Garrotxa volcanic zone natural park. Adapted from Casademunt 2018 [33].

\begin{tabular}{|c|c|c|c|}
\hline $\begin{array}{l}\text { Stages in the Policy and } \\
\text { Management of Nature } \\
\text { in Catalonia, Applied to } \\
\text { Public Use and } \\
\text { Environmental } \\
\text { Education in La } \\
\text { Garrotxa Volcanic Zone } \\
\text { Natural Park }\end{array}$ & $\begin{array}{l}\text { First Stage (1980-1991): } \\
\text { Distribution of Skills } \\
\text { and Separation of } \\
\text { Planning-Management }\end{array}$ & $\begin{array}{l}\text { Second Stage (1992-2010): } \\
\text { Lost Opportunities }\end{array}$ & $\begin{array}{c}\text { Third Stage (2011-2015): } \\
\text { Regression, Marginality and } \\
\text { Subordination }\end{array}$ \\
\hline $\begin{array}{l}\text { Information/interpretation } \\
\text { centers }\end{array}$ & $\begin{array}{l}\text { Casal dels volcans } \\
\text { (Volcano House). }\end{array}$ & $\begin{array}{l}\text { Expansion of the information } \\
\text { centers to include three more: } \\
\text { Can Serra for the Jordà beech } \\
\text { forest, Can Passavent for the } \\
\text { Croscat volcano, and the Sant } \\
\text { Feliu de Pallerols station. }\end{array}$ & $\begin{array}{l}\text { Reduction of information } \\
\text { centers: Sant Feliu de Pallerols } \\
\text { station. } \\
\text { Reduction of days and times at } \\
\text { the Casal dels Volcans and } \\
\text { Can Serra. } \\
\text { Paid parking in Can Serra and } \\
\text { Santa Margarida. }\end{array}$ \\
\hline Materials and resources & $\begin{array}{l}\text { Volcanological map. } \\
\text { First map of the natural } \\
\text { park. } \\
\text { Informative posters. }\end{array}$ & $\begin{array}{l}\text { Leaflets: map of the natural } \\
\text { park, more detailed routes. } \\
\text { Publications: volcanic activity } \\
\text { guide, reviewed } \\
\text { volcanological map. }\end{array}$ & $\begin{array}{l}\text { Payment for the map and } \\
\text { route leaflets. } \\
\text { Translations of the volcanic } \\
\text { activity guide. }\end{array}$ \\
\hline Routes and itineraries & $\begin{array}{l}\text { Creation of the first } \\
\text { network of itineraries } \\
\text { (14 itineraries). }\end{array}$ & $\begin{array}{l}\text { Creation of the other } \\
\text { itineraries (11 itineraries). }\end{array}$ & Creation of museum spaces. \\
\hline $\begin{array}{l}\text { Environmental } \\
\text { education }\end{array}$ & $\begin{array}{l}\text { School groups and } \\
\text { arbour day. }\end{array}$ & $\begin{array}{l}\text { Divisions of programs aimed } \\
\text { at two different users: } \\
\text { Local population and visiting } \\
\text { population. } \\
\text { New pedagogical offering. } \\
\text { Presence at the Sant Lluc fair } \\
\text { and in the media. } \\
\text { Resources and materials for } \\
\text { local schools. }\end{array}$ & $\begin{array}{l}\text { Removal of programs: School } \\
\text { and surrounding area, Sant } \\
\text { Lluc fair, radio programs. }\end{array}$ \\
\hline $\begin{array}{l}\text { Annual budget for the } \\
\text { natural park (average of } \\
\text { all the years) }\end{array}$ & $€ 800,000.00$ & $€ 1,750,000.00$ & $€ 800,000.00$ \\
\hline
\end{tabular}




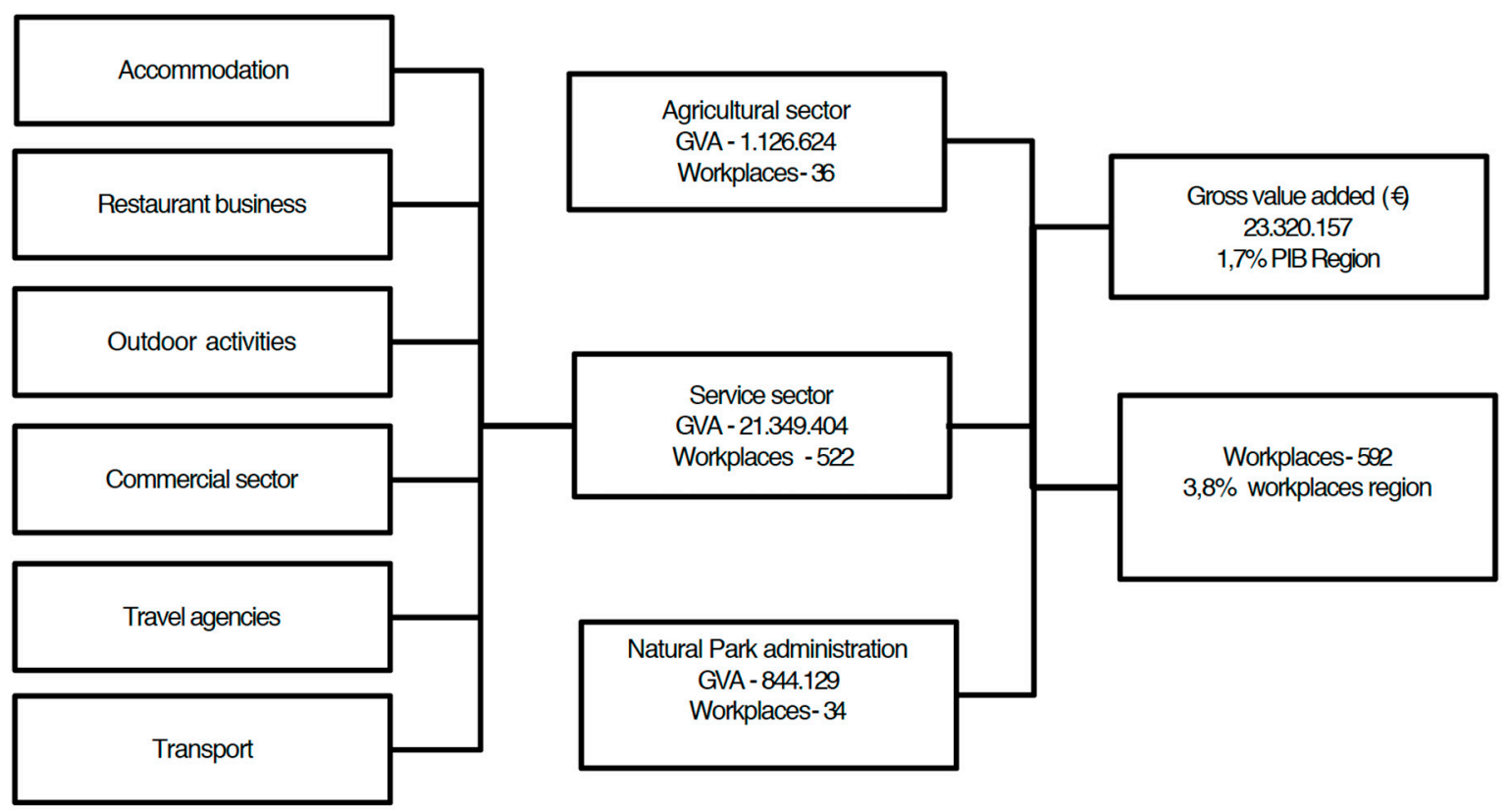

Figure 8. Calculation of the gross value added (GVA) per type of economic activity (social and economic impact of protected natural areas), jobs per types of activity, and totals (year 2012) (based on [20]).

\section{Socio-Economic Impact}

The number of people who, for different reasons, are interested in discovering these spaces that have been given special protection, is increasing every day. In Catalonia, for example, approximately 5.1 million people visited the different protected areas located in its territory in 2012, and 5.5 million visited in 2013 [24]. This means that a new economic activity has been developing alongside this type of tourism activity. At the same time, the protected natural areas act as ecosystem services, which are those services that people receive from ecosystems and that maintain, directly or indirectly, their quality of life [34].

As regards the economic value, its profit is clear according to Institut Cerdà 2015 [24] (Table 2). Despite the recession that affected Catalonia during the recent economic world crisis, for every $1 €$ that the administration has invested in the natural park of La Garrotxa, the return for the zone has been $8.8 €$. The economic impact of this protected space exceeds that produced by some of the country's top tourism attractions. For example, it represents more than double the economic impact generated by the Dalí Museum and the Gala-Salvador Dalí Foundation [24]. In the case of the volcanoes in La Garrotxa, this economic impact represents a total of $€ 23,320,157$ of annual gross added value (Table 2), which is equivalent to $1.7 \%$ of the gross value added (GVA) of the entire Garrotxa region. But the balance is also positive in employment since, directly or indirectly, the preservation and good management of the volcanoes in the zone has led to the creation of 592 jobs, representing 3.8\% of La Garrotxa employment [24] (Figure 8). The difference in the benefits obtained from the same volcanic zone when comparing a mining extraction that had four or five workers and conservation is clear, since benefits related to the second option have multiplied by ten. Moreover, another clear indicator of this economic benefit and the creation of jobs is that since the creation of the natural park, the offer of hotel beds has doubled in the area (Figure 9), thus supporting the fact that an efficient management of geological heritage is a suitable tool for sustainable tourism $[8,9]$. 


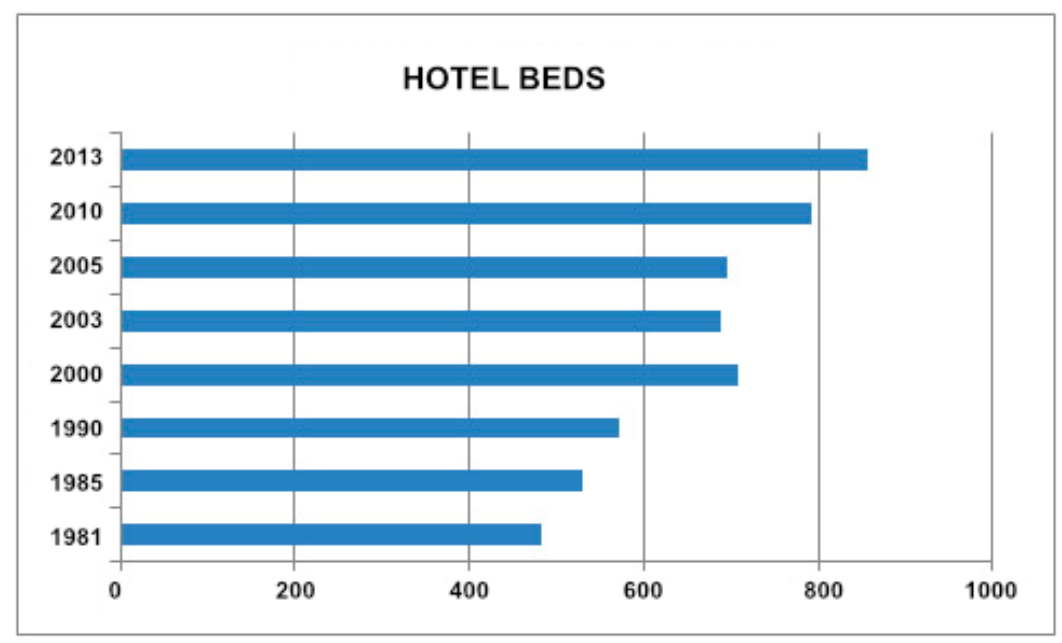

Figure 9. Evolution of the number of hotel beds available at La Garrotxa from the creation of the natural park in 1982 to date [23].

\section{Discussion and Conclusions}

The innovation of our research is to provide a clear description and quantification of the main benefits and threats that volcano tourism can represent for a particular protected area, thereby contributing to the improvement of scientific research and sustainable tourism. The natural park of La Garrotxa Volcanic Zone is a good example of how sustainable tourism represents a considerable benefit when efficient management is applied to geological heritage. From its creation in 1982 to the present day, the natural values have been preserved and this has implied a positive social and economic impact.

La Garrotxa Volcanic Zone clearly demonstrates that using geo-conservation as a tool for sustainable tourism is a good strategy to follow. If well-managed, it brings economic and social improvements to the area, not only in tourism, but also in the global image of the territory. This good image that the territory exports can be seen in the logos used by local companies and entities, as most of them show a clear reference to the volcanoes.

The positive social and economic impact that geotourism has had in La Garrotxa is based on different essential factors. One of these has been the scientific knowledge of the area. High-quality scientific research about La Garrotxa volcanoes has been important in assessing the best places to be promoted and providing correct and rigorous information to visitors. For this reason, cartography, guides, and data bases built in a suitable geographic information system have been essential. Another important aspect has been the involvement and co-management of local actors such as town councils and public and private entities. In this way, changes in environmental policies and budget cuts by the Catalan government (Table 2) can be overcome. The involvement of these actors means that there has been effective pressure to revert possible cuts and to become involved in management deficits. A better co-management of the area is still required in order to make progress in the conservation of the volcanoes, alongside the social and economic improvement that geotourism entails. This has been the key to be able to transmit the importance of the zone to visitors, to be able to generate a critical spirit in order to continue generating sustainability policies, and to prevent tourism from having serious ecological and social impacts. In this sense, the training and education programs that have been carried out for decades in La Garrotxa have been significant, which should be maintained in the future as a guarantee for its preservation and sustainable management.

The experience acquired at La Garrotxa can be exported to other protected areas with similar characteristics and potential problems. Looking at current trends in tourism, it is obvious that geotourism and volcano tourism will continue to grow. Therefore, it is important to prevent the potential problems this may cause. Despite the fact that each particular area may have different 
characteristics and, consequently, may undergo different problems related to geotourism, these may not differ so much from those identified in La Garrotxa. Hence, the same solutions applied here are recommended for other areas, in particular the application of revenue sharing and public and private investment to guarantee undertaking scientific research that can ensure a good knowledge of the natural values of the area, as well as the establishment of good training and education programs aimed at local populations and visitors in order to raise awareness about them.

Author Contributions: L.P. and J.M. have equally contributed to the conceptualization, definition of methodology, data analysis and curation, writing, reviewing, and editing of the current contribution.

Funding: This research received no external funding.

Acknowledgments: We would like to thank the staff of the Natural Park and La Garrotxa Tourism for providing essential information to elaborate this study.

Conflicts of Interest: The authors declare no conflict of interest.

\section{References}

1. Hose, T.A. Selling the story of Britain's stone. Environ. Interpret. 1995, 10, 16-17.

2. Hose, T.A. 3G's for Modern Geotourism. Geoherit. J. 2012, 4, 7-24. [CrossRef]

3. Newsome, D.; Dowling, R.K. Geotourism: The Tourism of Geology and Landscape; Goodfellow Publishers: Oxford, UK, 2010.

4. Hunter, C.J. On the need to re-conceptualise sustainable tourism development. J. Sustain. Tour. 1995, 3, 155-165. [CrossRef]

5. Hunter, C.J.; Green, H. Tourism and the Environment: A Sustainable Relationship? Routledge: London, UK, 1995.

6. Høyer, K.G. Sustainable Tourism or Sustainable Mobility? The Norwegian Case. J. Sustain. Tour. 2000, 8, 147-160. [CrossRef]

7. Dowling, R.K. Global Geotourism—An Emerging Form of Sustainable Tourism. Czech J. Tour. 2013, 2, 59-79. [CrossRef]

8. Sigurdsson, H.; Lopes-Gautier, R. Volcanoes and tourism. In Encyclopedia of Volcanoes; Sigurdsson, H., Houghton, B., McNutt, S.R., Rymer, H., Stix, J., Eds.; Academic Press: San Francisco, CA, USA, 2000; pp. 1283-1299.

9. Erfurt-Cooper, P. Geotourism in Volcanic and Geothermal Environments: Playing with Fire? Geoheritage 2011, 3, 187-193. [CrossRef]

10. Erfurt-Cooper, P. (Ed.) Volcanic Tourist Destinations. Geoheritage, Geoparks and Geotourism; Conservation and Management Series; Springer: Berlin/Heidelberg, Germany, 2014.

11. Dóniz-Páez, F.J. Reflexiones en torno al turismo volcánico. El caso de Islas Canarias, España. Pasos 2014, 12, 467-478. [CrossRef]

12. Eagles, P.F.J.; Bowman, M.E.; Tao, T.C.-H. Guidelines for Tourism in Parks and Protected Areas of East Asia; IUCN: Gland, Switzerland; Cambridge, UK, 2001.

13. Eagles, P.; McCool, S.F.; Haynes, C.D. Sustainable Tourism in Protected Areas: Guidelines for Planning and Management; Phillips, A., Ed.; IUCN: Gland, Switzerland; Cambridge, UK, 2002.

14. Spenceley, A.; Snyman, S.; Rylance, A. Revenue sharing from tourism in terrestrial African protected areas. J. Sustain. Tour. 2017. [CrossRef]

15. Munanura, I.E.; Backman, K.F.; Hallo, J.C.; Powell, R.B. Perceptions of tourism revenue sharing impacts on Volcanoes National Park, Rwanda: A Sustainable Livelihoods framework. J. Sustain. Tour. 2016, 24, 1709-1726. [CrossRef]

16. Nogué, J.; Sala-Martí, P. The Character of the Volcanic Landscape of La Garrotxa. In La Garrotxa Volcanic Field of Northeast Spain; Martí, J., Planagumà, L., Eds.; Springer Nature: Cham, Switzerland, 2017; pp. 1-26.

17. Martí, J.; Planagumà, L.; Geyer, G.; Canal, E.; Pedrazzi, D. Complex interaction between Strombolian and phreatomagmatic eruptions in the Quaternary monogenetic volcanism of the Catalan Volcanic Zone (NE of Spain). J. Volcanol. Geotherm. Res. 2011, 201, 178-193. [CrossRef]

18. Bolos, X.; Planaguma, L.; Martí, J. Volcanic stratigraphy of the Quaternary La Garrotxa Volcanic Field (north-east Iberian Peninsula). J. Quat. Sci. 2015, 29, 547-560. [CrossRef] 
19. Palou-Teixidor, O.; Boixadera-Llobet, J. Mapa de Sòls del Parc Natural de la Zona Volcànica de la Garrotxa: E: 1:25,000; PNZVG: Olot, Spain, 1999.

20. Araña, V.; Aparicio, A.; Martín-Escorza, C.; García-Cacho, L.; Ortiz, R.; Vaquer, R.; Barberi, F.; Ferrara, G.; Albert, J.; Gassiot, X. El volcanismo neó-geno-cuaternario de Cataluña: Caracteres estructurales, petrológicos y geodinámicos. Acta Geol. Hisp. 1983, 18, 1-17.

21. Guerin, G.; Benhamou, G.; Mallarach, J.M. Un exemple de fusió parcial en medi continental. El vulcanisme quaternari de Catalunya. Vitrina 1985, 1, 19-26.

22. Olivé, X. Habitats of La Garrotxa. In La Garrotxa Volcanic Field of Northeast Spain; Martí, J., Planagumà, L., Eds.; Springer Nature: Cham, Switzerland, 2017; pp. 45-54.

23. Natural Park of La Garrotxa Volcanic Zone. Personal Communication, 2018.

24. Obra Social La Caixa/Institut Cerdà. Impacte Econòmic i Social dels Espais Naturals Protegits; Departament de Territori i Sostenibilitat de la Generalitat de Catalunya: Barcelona, Spain, 2015.

25. Martí, J.; Plangumà, L.; de Bolós, X. Geosites and Geoitineraries. In La Garrotxa Volcanic Field of Northeast Spain; Martí, J., Planagumà, L., Eds.; Springer Nature: Cham, Switzerland, 2017; pp. 69-84.

26. Tresserras, M.; Oliver, X.; Planagumà, L. Cultural and Natural Sites. In La Garrotxa Volcanic Field of Northeast Spain; Martí, J., Planagumà, L., Eds.; Springer Nature: Cham, Switzerland, 2017; pp. 85-98.

27. Martí, J.; Pujades, A.; Ferrés-Lopez, D.; Planagumà, L.; Mallarach-Carrera, J.M. El Vulcanisme: Guia de Camp de la Zona Volcànica de la Garrotxa; PNZVG: Olot, Spain, 2000.

28. Mallarach, J.M. Carta Geologica de la Regió Volcanica d'Olot. Litologia i Geomorfologia 1120.000; Ajuntament d'Olot: Olot, Spain, 1982.

29. Bonet, O. Educational Programmes. In La Garrotxa Volcanic Field of Northeast Spain; Martí, J., Planagumà, L., Eds.; Springer Nature: Cham, Switzerland, 2017; pp. 98-108.

30. Prats, J.M.; Bassols, E. La Garrotxa Volcanic Zone, Spain. In Volcanic Tourist Destinations. Geoheritage, Geoparks and Geotourism; Erfurt-Cooper, P., Ed.; Conservation and Management Series; Springer: Berlin/Heidelberg, Germany, 2014; pp. 139-143.

31. Turisme Garrotxa. The Land of Volcanoes. Available online: http://en.turismegarrotxa.com/home/ (accessed on 8 July 2018).

32. Pijuan, J. Estudi de la Freqüentació Turística a la Fageda d'en Jordà (Sender Joan Maragall); Segon Trimestre INTERNAL Report; PNZVG: Olot, Spain, 2014.

33. Casademunt, A. Política i gestió de la natura a Catalunya (1980-2016): El llast d'un conflicte polític i social entre desiguals. In Canvi d'Època i de Polítiques Públiques a Catalunya; Gomà, R., Subirats, J., Eds.; Crític Sccl: Barcelona, Spain, 2017; pp. 201-207.

34. Millennium Ecosystem Assessment. Ecosystems and Human Well-Being; Island Press: Washington, DC, USA, 2014.

(C) 2018 by the authors. Licensee MDPI, Basel, Switzerland. This article is an open access article distributed under the terms and conditions of the Creative Commons Attribution (CC BY) license (http://creativecommons.org/licenses/by/4.0/). 